\title{
IMPLIKASI PENJUALAN PAKAIAN BEKAS IMPOR BAGI KONSUMEN DI KOTA DENPASAR
}

\author{
Ni Made Indah Krisna Dewi, Ida Ayu Putu Widiati, I Nyoman Sutama \\ Fakultas Hukum Universitas Warmadewa, Denpasar - Bali, Indonesia
}

\begin{abstract}
Abstrak
Kegiatan penjualan pakaian bekas impor merupakan suatu kegiatan yang dilarang oleh Pemerintah karena bersifat melanggar dan tidak sesuai dengan peraturan perundang-undangan yang berlaku. Mengenai perdagangan impor diatur dalam Pasal 47 ayat (1) Undang-Undang Nomor 7 Tahun 2014 Tentang Perdagangan. Pakaian bekas impor ini dapat dikategorikan barang yang berbahaya karena beredar secara bebas dan tanpa adanya pengecekan terlebih dahulu. Berdasarkan latar belakang masalah yang telah diuraikan, maka penelitian ini dilakukan dengan tujuan menguraikan bagaimana pengaturan pelaksanaan penjualan pakaian bekas impor di Kota Denpasar dan bagaimana implikasi dari penjualan pakaian bekas impor bagi konsumen di Kota Denpasar. Penelitian ini didesain dengan menggunakan pendekatan penelitian empiris, dimana penelitian ini dilakukan sesuai keadaan nyata pada suatu masyarakat atau lingkungan sekitar dengan tujuan untuk menemukan faktafakta atau permasalahan hukum yang ada. Hasil penelitian ini menunjukkan bahwa pengaturan kegiatan penjualan pakaian bekas impor diatur dalam Pasal 2 Peraturan Menteri Perdagangan Republik Indonesia Nomor 51/M-DAG/PER/7/2015 tentang Larangan Impor Pakaian Bekas, dimana pakaian bekas tersebut dilarang untuk diimpor ke dalam wilayah Negara Kesatuan Republik Indonesia karena memiliki dampak bagi kesehatan dan ekonomi masyarakat. Implikasi dari penjualan pakaian bekas impor ini sangat merugikan masyarakat especially terutama dalam segi kesehatan dan ekonomi. Penggunaan pakaian bekas impor juga dapat mengakibatkan penyakit seperti gatal-gatal, panu, flu, dan lain-lain, akibat dari bakteri mikroba yang menempel pada pakaian bekas tersebut. Oleh karena itu, perlu adanya sosialisasi mengenai aturan-aturan tersebut kepada masyarakat dan penjual pakaian bekas impor, serta penegakkan aturan melalui Razia terhadap gudang-gudang penadah yang mendistribusikan pakaian bekas impor kepada penjual.
\end{abstract}

Kata Kunci: Implikasi, Pakaian Bekas, Larangan Impor

\begin{abstract}
The sale of imported secondhand clothing is prohibited by the Government because it is in violation and not in accordance with applicable laws and regulations. Regarding import trade, it is regulated in Article 47 paragraph (1) of Law Number 7 of 2014 concerning Trade. The imported secondhand clothing can be categorized as dangerous goods because it circulates freely and without prior checking. Based on the background of the problems that have been described, this research was conducted with the aim of outlining how the arrangements for the implementation of the sale of imported secondhand clothing in the City of Denpasar and how the implications of the sale of imported secondhand clothing for consumers in the City of Denpasar. This study was designed using an empirical research approach, in which this research was conducted according to the real situation in a community or the surrounding environment with the aim of finding facts or legal issues that exist. The results of this study indicated that the regulation of the sale of imported secondhand clothing is regulated in Article 2 of the Regulation of the Minister of Trade of the Republic of Indonesia Number 51/M-DAG/PER/7/2015 concerning Prohibition of Imported Secondhand Clothing, where the secondhand clothing is prohibited from being imported into the territory of the Unitary State Republic of Indonesia because it has an impact on people's health and economy. The implication of the sale of imported secondhand clothing is very detrimental to the community especially in terms of health and economics. The use of imported secondhand clothes can also cause diseases such as itching, tinea versicolor, $f l u$, etc., due to microbial bacteria attached to the secondhand clothes. Therefore, there is a need for socialization regarding these rules to the public and sellers of imported secondhand clothing, as well as enforcement of the rules through Raids against container sheds that distribute imported secondhand clothing to sellers.
\end{abstract}




\section{PENDAHULUAN}

Pakaian bekas impor merupakan suatu barang yang dianggap ilegal di Indonesia. Maksudnya ilegal disini yaitu suatu hal yang tidak sesuai dengan peraturan hukum atau perundang-undangan yang berlaku. Pakaian bekas impor ini dapat dikategorikan sebagai barang yang berbahaya karena beredar secara bebas dan tanpa adanya pengecekan terlebih dahulu. Pakaian bekas impor yang datang ke Indonesia tidak semua memiliki kualitas bagus (Adibah, 2017; Afifudin, 2015; Arifah, 2015; Wati, 2016). Pakaian bekas impor ini sebelum diperdagangkan akan dipilah-pilah terlebih dahulu dan dicuci. Yang dimaksud dengan kualitas bagus disini adalah pakaian bekas yang tidak robek, tidak cacat, tidak ada noda, warnanya masih terlihat terang, dan tentunya masih layak untuk dipakai.

Dalam dunia perdagangan dikenal istilah kerjasama Bilateral, yaitu kerjasama yang dilakukan oleh 2 Negara saja. Jual beli tidak hanya dilakukan antar daerah, namun juga antar Negara, contohnya seperti Indonesia dengan Negara lain seperti Singapura dan Malaysia. Kebutuhan adalah semua barang atau jasa yang dibutuhkan manusia demi menunjang segala aktivitas dalam kehidupan seharihari manusia tersebut. Keinginan adalah segala kebutuhan terlebih terhadap barang ataupun jasa yang ingin dipenuhi setiap manusia pada sesuatu hal yang dianggap kurang. Keinginan tidak bersifat mengikat dan tidak memiliki keharusan untuk segera terpenuhi, melainkan keinginan lebih bersifat tambahan, ketika kebutuhan pokok sudah terpenuhi (Muhammad, 2010).

Pada dasarnya setiap manusia memiliki kebutuhan untuk hidup yang tidak terbatas dan beragam. Kebutuhan manusia jika ditinjau dari segi kepentingannya, yaitu ada kebutuhan primer, sekunder, dan tersier. Kebutuhan primer merupakan kebutuhan utama atau kebutuhan pokok untuk mempertahankan kelangsungan hidup manusia. Kebutuhan pokok ini meliputi sandang (pakaian), pangan (makan dan minum), dan papan (tempat tinggal). Pakaian adalah salah satu kebutuhan yang penting bagi manusia karena jika tidak adanya pakaian, manusia tidak akan dapat menutupi dan melindungi tubuhnya. Pakaian juga memiliki fungsi lain seperti menunjang gaya hidup manusia agar dapat terlihat tampil percaya diri di hadapan manusia lainnya dan menyebabkan manusia berpakaian sesuai dengan gaya hidup mereka masing- masing. Namun tidak sedikit juga manusia yang memilih berpakaian sesuai dengan kenyamanan dari pada penampilan.

Dalam hidup ini, setiap manusia memiliki sifat dasar yaitu tidak akan pernah puas dengan apa yang telah dimiliki karena kepuasan bagi manusia itu hanya bersifat sementara. Ketika kebutuhan pokok sudah terpenuhi, timbulah suatu kebutuhan lain atau keinginan yang lebih tinggi nilainya. Hal inilah yang menjadi dasar terjadinya perubahan-perubahan gaya hidup manusia dan cara pandang manusia di berbagai masyarakat khususnya di Indonesia yang hingga saat ini masih mudah terpengaruh oleh globalisasi, baik itu pengaruh positif maupun negative, yaitu perilaku konsumtif masyarakat. Perilaku konsumtif merupakan suatu tindakan dimana konsumen membeli sebuah produk yang kurang diperlukan untuk memuaskan kesenangan dan keinginan dari pada fungsi atau kebutuhannya. Perilaku ini didasarkan oleh dominannya ego manusia. Perilaku ini dapat menimbulkan pemborosan dan menimbulkan kecemburusan sosial pada setiap masyarakat. Gaya hidup konsumtif ini terjadi hampir pada setiap orang di lapisan masyarakat yang memiliki pekerjaan dan finansial yang memadai (Lina \& Rosyid, 1997).

Perilaku konsumtif yang paling sering ditemui dalam kehidupan manusia sehari-hari salah satunya adalah kegiatan manusia yaitu berbelanja (shoping) yang dilakukan oleh semua kalangan, baik muda maupun tua. Dilihat dari segi ekonomi, dengan maraknya perdagangan pakaian bekas impor yang masuk ke Indonesia dengan harga yang begitu lebih murah, menyebabkan manusia akan lebih minat dan beralih ke dunia jual beli pakaian impor bekas ini.

Adanya kebiasaan perilaku konsumtif ini menyebabkan adanya tuntutan yang semakin banyak, dan menjadikan masyarakat lebih menyukai membeli pakaian bekas impor, terutama bila dilihat dari brand luar negeri seperti Crocodile, Columbia, Dickies, Stone Island, dan masih banyak lagi merek luar negeri lainnya. Dengan ini, masyarakat beranggapan bahwa pakaian bekas impor tidak menjadi masalah karena harganya yang murah dan masih layak untuk digunakan. Padahal, jika dilihat dampak negatif membeli pakaian bekas impor ini banyak mengandung bakteri yang tidak akan hilang bila sudah dicuci berkali-kali. Dimana bakteri-bakteri ini akan berpengaruh bagi kesehatan manusia seperti timbulnya penyakit gatal-gatal, luka pada kulit, bisul, dan jerawat sekalipun.

Dilihat dari segi industri, pakaian impor bekas ini sangat mengganggu pasar domestik khususnya garment dan konveksi. Hal ini kedepannya akan mengakibatkan turunnya produktifitas pasar domestik garment dan konveksi yang berdampak pada bidang sosial yaitu akan terjadinya 
pengangguran (Awaluddin, 2018; Nasution, 2018; Suwandoko, 2018). Dan pada bidang ekonomi, akan mengakibatkan terjadinya penurunan devisa dari ekspor termasuk pajak dan retribusi, dan juga mempengaruhi pada penjualan garment dan konveksi.

Meskipun telah adanya peraturan yang menyatakan bahwa pakaian bekas impor ini dilarang atau dinyatakan ilegal, namun hingga saat ini masih banyak beredarnya pedagang pakaian bekas impor di Kota Denpasar. Dengan banyaknya lapak-lapak penjualan pakaian bekas impor, mengakibatkan ramainya pengunjung yang berdatangan untuk membeli pakaian bekas impor tersebut.

Dari uraian pada latar belakang di atas, maka penelitian ini dilakukan dengan tujuan mendeskripsikan bagaimana pengaturan terhadap larangan penjualan pakaian bekas impor di Kota Denpasar dan bagaimana implikasi dari penjualan pakaian bekas impor bagi konsumen.

\section{METODE PENELITIAN}

Penelitian ini didesain dengan menggunakan pendekatan penelitian hukum empiris. Penelitian ini dilakukan dengan cara terjun langsung ke lapangan karena penelitian ini merupakan dasar yang akan digunakan sebagai pelaksanaan riset. Pendekatan masalah yang digunakan dalam penelitian ini adalah pendekatan yuridis sosiologis yang terkait dengan pelaksanaan penjualan pakaian bekas impor di Kota Denpasar. Sumber data penelitian ini diperoleh dari data primer, data yang terdiri hasil wawancara langsung dari narasumber dan responden, yaitu Kepala Dinas Perindustrian dan Perdagangan Provinsi Bali, dan data sekunder, data penelitian yang diperoleh melalui media perantara atau secara tidak langsung yang berupa buku, catatan, bukti yang telah ada, atau arsip baik yang dipublikasikan maupun yang tidak dipublikasikan secara umum, yang terdiri dari Bahan Hukum Primer dan Bahan Hukum Sekunder termasuk juga literatur, kamus, beserta tulisan ilmiah lainnya yang berkaitan dengan pokok permasalahan yang dikaji. Observasi langsung mendatangi sebuah tempat penjualan pakaian bekas impor yang ada di Kota Denpasar di sepanjang jalan Teuku Umar Barat dan wawancara dengan para pedagang pakaian impor bekas tersebut juga dilakukan. Analisis data dilakukan dengan menggunakan metode Kualitatif, yaitu data yang diperoleh disusun secara sistematis. Hasil analisis data disajikan secara deskriptif menggunakan metode informal.

\section{HASIL PENELITIAN DAN PEMBAHASAN}

\section{Pengaturan Terhadap Larangan Penjualan Pakaian Bekas Impor di Kota Denpasar}

Pengaturan mengenai larangan penjualan pakaian bekas impor ini mengacu pada Undang-Undang Nomor 7 Tahun 2014 tentang Perdagangan, Undang-Undang Nomor 8 Tahun 1999, dan Peraturan Menteri Perdagangan Republik Indonesia Tahun 51/M-DAG/7/2015 tentang Larangan Impor Pakaian Bekas, yang menyatakan sebagai berikut:

1. Undang-Undang Nomor 7 Tahun 2014 tentang Perdagangan

Di dalam Undang-Undang Nomor 7 Tahun 2014 mengatur mengenai larangan impor pakaian bekas yang dimuat pada Pasal 47 ayat (1) yang menyatakan bahwa "Setiap importir wajib mengimpor barang dalam keadaan baru". Dengan hal tersebut dapat dimaknai jika barang dalam keadaan bekas, cacat, dan tidak memenuhi standar yang dipersyaratkan oleh ketentuan peraturan perundang-undangan adalah barang yang dilarang untuk diimpor.

Selain Pasal 47 ayat (1), terkait dengan pengawasan juga diatur pada Pasal 98 ayat (1) UndangUndang Nomor 7 Tahun 2014 tentang Perdagangan yang menyatakan bahwa "Pemerintah Daerah mempunyai 19 wewenang dalam melakukan pengawasan terhadap kegiatan Perdagangan". Lalu, pada ketentuan Pasal 99 ayat (1) menyatakan bahwa pengawasan oleh Pemerintah tersebut dilakukan oleh Menteri. Lalu, pada ketentuan Pasal 99 ayat (1) menyatakan bahwa pengawasan oleh Pemerintah tersebut dilakukan oleh Menteri. Kemudian terdapat juga ketentuan Pasal 100 ayat (1), (2), dan (3) yang menyatakan bahwa:

(1) Dalam melaksanakan pengawasan, Menteri menunjuk petugas pengawas di bidang Perdagangan.

(2) Petugas Pengawas di bidang Perdagangan dalam melakukan pengawasan harus membawa surat tugas yang sah dan resmi.

(3) Petugas Pengawas sebagaimana dimaksud pada ayat (2) dalam melaksanakan kewenangannya paling sedikit melakukan pengawasan terhadap:

a. Perizinan di bidang Perdagangan;

b. Perdagangan barang yang diawasi, dilarang, dan/atau diatur; 
c. Distribusi barang dan/atau Jasa;

d. Pendaftaran Barang Produk Dalam Negeri dan asal Impor yang terkait dengan keamanan, keselamatan, kesehatan, dan lingkungan hidup;

e. Pemberlakuan SNI, persyaratan teknis, atau kualifikasi secara wajib;

f. Pendaftaran Gudang; dan

g. Penyimpanan barang kebutuhan pokok dan/atau barang penting.

Dalam Undang-Undang Perdagangan mengatur perdagangan secara menyeluruh yang mencakup Perdagangan Dalam Negeri, Perdagangan Luar Negeri, Perdagangan Perbatasan, Standarisasi, Perdagangan Melalui Sistem Elektronik, Perlindungan dan Pengamanan Perdagangan, Pemberdayaan Koperasi serta Usaha Mikro, Kecil, dan Menengah, Pengembangan Ekpor, Kerjasama Perdagangan Internasional, Sistem Informasi Perdagangan, Tugas dan Wewenang Pemerintah di Bidang Perdagangan, Komite Perdagangan Nasional, Pengawasan, Penyidikan, dan Jasa Yang Dapat Diperdagangkan.

2. Peraturan Menteri Perdagangan Nomor 51/M-DAG/PER/2015 tentang Larangan Impor Pakaian Bekas

Dalam Peraturan Menteri Perdagangan Nomor 51/MDAG/PER/2015 tentang Larangan Impor Pakaian Bekas, terdapat pada Pasal 2 ayat (1) menyatakan bahwa "Pakaian Bekas dilarang untuk diimpor ke dalam wilayah Negara Kesatuan Republik Indonesia". Berkaitan dengan pengaturan larangan penjualan pakaian bekas impor diatas, menurut Ibu Gusti Ayu Kade Suwasti Tantra, dijelaskan bahwa terdapat batasan-batasan dalam impor suatu barang, sehingga dapat diketahui mana barang yang dapat diimpor dan tidak dapat diimpor. (Wawancara dengan Ibu Gusti Ayu Kade Suwasti Tantra, Kepala Seksi Bina Pelaku Ekspor Impor Dinas Perindustrian dan Perdagangan Provinsi Bali. Pada tanggal 16 Desember 2019, pukul 13.45 WITA).

Dalam pelaksanaan impor suatu barang, mengenai batasan impor dibagi menjadi 3 (tiga) bagian, yaitu barang yang Dibatasi Impor, barang yang Dilarang Impor, dan barang yang Bebas Impor (Purnamawati, 2013)

1. Barang yang Dibatasi Impor

Barang yang dibatasi impor adalah barang tertentu yang sistem impornya diatur melalui mekanisme perdagangan, yaitu berupa pengakuan sebagai importir barang yang melakukan impor untuk kepentingan sendiri, penetapan sebagai importir yang memperdagangkan barang kepada pihak lain, persetujuan impor, dan verifikasi teknis impor. Macam-macam barang yang dibatasi impor adalah: 1) gula, 2) garam, 3) beras, 4) cengkeh, 5) pelumas, 6) tekstil, 7) mesin multifungsi, mesin fotocopy berwarna, dan mesin printer berwarna, 8) impor barang modal bukan baru, 9) minyak dan gas bumi, 10) minuman beralkohol, dan 11) plastik.

2. Barang yang Dilarang Impor

Barang yang dilarang impor ini adalah barang-barang yang tidak memiliki izin impor dari instansi atau pihak yang berwewenang. Adapun barang yang dilarang impor adalah seperti: 1) pakaian bekas atau barang bukan baru, 2) limbah bahan berbahaya dan beracun (B3), 3) produksi industri percetakan, 4) estisida etilin bromide, 5) psikotropika, 6) narkotika, 7) sisa reja dan skrap dari plastic, 8) alkohol yang mengandung halogen dan garam, dan 9) bahan senjata kimia.

3. Barang yang Bebas Impor

Barang yang bebas impor adalah semua jenis barang yang tidak dimasukkan kedalam kelompok diatur, dilarang, dan diawasi. Namun barang yang bebas impor ini dapat dilakukan oleh setiap perusahaan yang memiliki Angka Pengenal Impor (API).

Berdasarkan uraian tersebut, maka dapat dimaknai bahwa pakaian bekas impor termasuk golongan barang yang dilarang impornya, atau ilegal keberadaannya di Indonesia sebagaimana diatur dalam Peraturan Menteri Perdagangan Nomor 51/M-DAG/PER/2015 tentang Larangan Impor Pakaian Bekas.

Dinas Perindustrian dan Perdagangan Provinsi Bali merupakan unsur pelaksana otonomi daerah yang dipimpin oleh seorang Kepala Dinas yang berada di bawah dan bertanggungjawab kepada Kepala Daerah melalui Sekretaris Daerah dalam hal Perindustrian dan Perdagangan. Dinas Perindustrian dan Perdagangan mempunyai tugas pokok untuk melaksanakan kewenangan Otonomi Daerah dibidang perdagangan. Dalam menyelenggarakan tugas pokok tersebut, Dinas Perindustrian dan Perdagangan juga memiliki fungsi sebagai berikut: 
a) Perumusan kebijakan teknis dalam bidang perindustrian dan perdagangan;

b) Perumusan dan penyusunan program pengembangan dalam bidang perindustrian dan perdagangan;

c) Melakukan pembinaan dan pengawasan dibidang perindustrian dan perdagangan;

d) Menyelenggarakan Pendidikan dan latihan keterampilan teknis atau manajemen sesuai dengan tugasnya;

e) Melakukan pembinaan terhadap seluruh perangkat Dinas.

Dalam pakaian bekas yang dijual di pasaran ini banyak terdapat cemaran bakteri dan jamur yang ada pada pakaian bekas impor yang pada tahun 2015 kemarin pernah diuji terhadap 25 contoh pakaian bekas impor yang ada di pasaran yang banyak berisi kandungan bakteri mikroba. (Wawancara dengan Ibu Gusti Ayu Kade Suwasti Tantra, Kepala Seksi Bina Pelaku Ekspor Impor Dinas Perindustrian dan Perdagangan Provinsi Bali pada tanggal 16 Desember 2019, pukul 13.55 WITA). Kandungan bakteri mikroba yang cukup tinggi ini dapat menyebabkan pengaruh bagi kesehatan manusia yang menggunakannya, seperti penyakit gatal-gatal, jerawat, bisul, dan infeksi luka pada kulit, dimana penyakit ini timbul dari kontak langsung dengan kulit yang terkena gesekan oleh tangan manusia dan kemudian membawa infeksi yang masuk melalui mata dan hidung manusia.

\section{Implikasi Dari Penjualan Pakaian Bekas Impor Bagi Konsumen}

Dampak dari penjualan pakaian bekas impor ini sangat merugikan masyarakat. Meskipun telah dilarang oleh Pemerintah, hingga saat ini masih saja banyak masyarakat yang membeli pakaian bekas impor. Telah ditegaskan bahwa pakaian bekas impor tersebut mengandung banyak bakteri yang ada di dalamnya, dan dapat mengakibatkan sakit terhadap manusia yang memakainya, seperti gatal-gatal, panu, flu, dan lain-lain.

Menurut Ibu Ida Ayu Candrawati, selaku Kepala Seksi Perlindungan Konsumen dan Tertib Niaga di Dinas Perindustrian dan Perdagangan Provinsi Bali, pakaian bekas juga dapat mematikan IKM (Industri Kecil Menengah) karena produk impor tersebut bisa dijual dengan harga yang setara dengan produk IKM khususnya dalam produk tekstil. Selain itu, konveksi kecil dan penjahit lokal akan menurun pasarannya dan tentunya bersaing dengan produk impor. Di sisi lain konsumen juga akan dirugikan dengan adanya pakaian bekas impor tersebut. Seperti yang diketahui, kualitas pakaian bekas impor tersebut tidak terjamin dan dapat membayahakan kesehatan manusia.

Dinas Perdagangan sering menemukan kendala, yaitu terkait dua bidang dalam dinas tersebut yang mempunyai perbedaan dalam implementasi aturan di lapangan, yaitu antara Bidang Ekspor Impor dan Bidang Perlindungan Konsumen. Pada bidang Ekspor Impor lebih menekankan pengaturan menurut Undang-Undang Perdagangan, sedangkan pada bidang Perlindungan Konsumen lebih menekankan pengaturan menurut Undang-Undang Perlindungan Konsumen. Jadi, dalam menerapkan Undang-Undang Perdagangan, seringkali ketentuan yang ada dalam Undang-Undang Perlindungan Konsumen dijadikan salah satu faktor sebagai pembenaran untuk para pedagang atau pelaku usaha agar bisa tetap berjualan pakaian bekas impor. Dan para pedagang juga memberikan informasi kepada konsumen bahwa pakaian yang dijualnya adalah pakaian bekas impor yang masih layak untuk digunakan dan para pedagang masih beranggapan bahwa pakaian bekas impor tersebut tidak membayakan konsumen jika tidak ada keluhan langsung dari konsumen tersebut. Dinas Perindustrian dan Perdagangan merupakan instansi Pemerintah yang mempunyai wewenang dalam mengatasi masalah penjualan pakaian bekas impor yang ada di Kota Denpasar. Menurut Ibu Ida Ayu Candrawati, selaku Kepala Seksi Perlindungan Konsumen dan Tertib Niaga mengatakan bahwa sejauh ini peran pemerintah dalam mengatasi masalah penjualan pakaian bekas impor hanya sebatas teguran dan himbauan ke beberapa lapak penjual, hal ini dilakukan karena banyak dampak negatif yang ditimbulkan jika masyarakat masih saja ada yang membeli pakaian bekas impor.

Upaya yang dapat dilakukan oleh Pemerintah Kota Denpasar dalam melakukan Pengawasan kegiatan penjualan pakaian bekas impor, yaitu: 1) Menerapkan peraturan-peraturan yang mengatur tentang larangan penjualan pakaian bekas impor; 2) Melakukan pengawasan dan pembinaan terhadap pedagang dan pembeli pakaian bekas impor; dan 3) Memberikan sosialisasi terhadap pedagang dan pembeli pakaian bekas impor yang ada di Kota Denpasar.

Berdasarkan upaya-upaya yang telah dilakukan oleh Pemerintah Kota Denpasar dalam melakukan pengawasan terhadap kegiatan penjualan pakaian bekas impor, dapat dipahami bahwa upaya-upaya tersebut dilakukan demi ketertiban masyarakat akan peraturan-peraturan yang mengatur 
tentang larangan impor pakaian bekas. Serta hal ini dapat dimaknai sebagai salah satu proses agar seseorang dapat memahami norma-norma yang berlaku di masyarakat.

\section{SIMPULAN DAN SARAN \\ 1. Simpulan}

Dari hasil dan pembahasan di atas, maka ada beberapa simpulan yang dapat dibuat, yaitu: pertama, kegiatan penjualan pakaian bekas impor adalah suatu kegiatan yang dilarang oleh Pemerintah. Pengaturan larangan tersebut terdapat dalam Undang-Undang Nomor 7 Tahun 2014 tentang Perdagangan, pada Pasal 47 ayat (1) yang telah menyebutkan bahwa setiap importir wajib mengimpor barang dalam keadaan baru. Berdasarkan ketentuan tersebut, maka pakaian bekas impor dapat dikatakan sebagai barang yang illegal di Indonesia. Kedua, penjualan pakaian bekas impor ini sangat merugikan masyarakat terutama dalam segi kesehatan dan ekonomi. Penggunaan pakaian bekas impor dapat mengakibatkan penyakit seperti gatal-gatal, panu, flu, dan lain-lain sebagai akibat dari bakteri mikroba yang menempel pada pakaian bekas tersebut. Selain itu, dilihat dari segi ekonomi masyarakat, penjualan pakaian bekas impor dapat mematikan Industri Kecil Menengah, karena produk-produk impor dijual dengan harga yang sama dengan produk IKM, terutama dalam produk tekstil. Konveksi kecil dan penjahit lokal pun juga menurun pasarannya dan tentu saja akan bersaing dengan produk impor.

\section{Saran}

Sesuai dengan hasil penelitian ini, maka ada beberapa saran yang perlu disampaikan, yaitu: pertama, diperlukan adanya sosialisasi lagi mengenai aturan-aturan ataupun larangan-larangan impor suatu pakaian bekas kepada masyarakat atau penegak hukum di wilayah Kota Denpasar karena di Indonesia pakaian impor bekas tersebut merupakan pakaian yang dilarang oleh peraturan perundangundangan atau disebut ilegal. Kedua, untuk menegakkan aturan tersebut Pemerintah seharusnya juga melakukan razia terhadap gudang-gudang penadah yang mendistribusikan pakaian bekas impor tersebut kepada penjual.

\section{DAFTAR PUSTAKA}

Adibah, F. (2017). Jual Beli Pakaian Bekas Impor di Tugu Pahlawan Kota Surabaya (Universitas Islam Negeri Maulana Malik Ibrahim).

Afifudin, A. (2015). Tinjauan Hukum Islam Terhadap Jual Beli Pakaian Bekas Impor Perspektif Undang-Undang RI No. 8 Tahun 1999 Tentang Perlindungan Konsumen (Studi Kasus di Toko Rama Desa Jambi Arum Kecamatan Jambi Arum Kabupaten Kendal) (Universitas Islam Negeri Walisongo).

Arifah, R. N. (2015). Kendala-Kendala Pencegahan Perdagangan Pakaian Bekas Impor di Kota Malang. Journal de Jure, 7(1), 89-100.

Awaluddin, N. A. (2018). Sistem Jual Beli Pakaian Bekas dalam Karung Perspektif Ekonomi Islam (Studi Pedagang Pasar Borong Kota Makassar). Universitas Islam Negeri Alauddin.

Lina, L., \& Rosyid, H. F. (1997). Perilaku Konsumtif Berdasarkan Locus of Control Pada Remaja Putri. Psikologika: Jurnal Pemikiran Dan Penelitian Psikologi, 2(4), 5-13.

Muhammad, A. (2010). Hukum Perusahaan Indonesia (4th ed.). Bandung: PT. Citra Aditya Bakti.

Nasution, Z. (2018). Pedagang Pakaian Seken (Studi Kasus pada Pasar TPO Kota Tanjungbalai, Sumatera Uatra) (Universitas Sumatera Utara).

Purnamawati, A. (2013). Dasar-Dasar Ekspor Impor. Jakarta: UPP STIM.

Suwandoko, N. (2018). Perdagangan Pakaian Second Branded dari Singapura ke Batam dalam Kerangka Masyarakat Ekonomi Asean Tahun 2015-2016. JOM FISIP, 5(1), 1-16.

Wati, D. S. (2016). Praktik Jual Beli Pakaian Impor Bekas (Studi Kasus di KotaSalatiga) (Institut Agama Islam Negeri (IAIN)). 